\title{
The Influence of Famliy Socio-Economic Condition on Learning Motivation in Ensino Basico Central Daisoli Aileu District Timor Leste
}

\author{
Sebastião Pereira \\ Fakultas Ilmu Pendidikan, Instituto Superior Cristal \\ Balide - Dili, Timor Leste \\ sebastiao.cristal@yahoo.co.id
}

\author{
Helena A. Salsinha \\ Fakultas Ilmu Pendidikan, Instituto Superior Cristal \\ Balide - Dili, Timor Leste \\ helena.salsinha@yahoo.co.id
}

\begin{abstract}
The aim of this study is to discover and analyze the influence of family socio-economic condition on students' learning motivation in Ensino Basico Central Daisoli Aileu District, Timor Leste. This study employed qualitative design and was utilizing simple linear regression analysis technique. The result of this study demonstrates that the value of $t_{\text {count }}$ of 7.091 $>\mathrm{t}_{\text {table }}$ of 1.701 at the significance value of 0.005 . In addition, the linear equation of simple regression model is $\mathrm{Y}=11.381+$ $0.645 \mathrm{X}$. The correlation coefficient equals to 0.801 and determinant coefficient value (R2) eqauls to 0.642 or $64.2 \%$ which means that $64.2 \%$ students' learning motivation is influenced by economic ocndition of the family. In conclusion, the increasing of students' learning motivation relies upon the economic condition of the family. The more the family economic condition are advanced the students' learning motivation increases since by having an advanced economic condition, it fulfills the daily necessity of students.
\end{abstract}

Keywords: socio-economic condition, family, learning motivation

\section{INTRODUCTION}

Basically, educational process could occur in any social context within human beings. In general, educational process could occur in three educational settings, family (informal education), school (formal education), and social circumstance (non-formal education). By providing a holistic education, it can develop the quality characters of children as learners and actualize the potential within themself. In addition, such human resources is required in present situation and in the upcoming situation dealing with competitive and reliable source, as well as distinctive characteristics, high social awareness, and high faith (Hasan, 1990).

Pursuant to Republica Demokratica de Timor Leste (RDTL) Constitution article 59, it explains that the state will recognize and grant each society rights regarding education and culture. In addition, the state ought to ensure the development of basic education system universally and free education if it is possible.

Socio-economic condition of family highly influence within the entire aspects of the learners, including learning activity and the motivation. If the socio-economic condition of family is not feasible or limited, it influences the learners' learning motivation in school. Motivation occurs due to its necessity in certain context and circumstance. Learning is dominantly influenced by the interest of learning since it serves as the stimulant of learners to concéntrate, be motivated, or encourage a competitive during the study. Motivation is defined as willingness or desire comes within the person or individual. Each educational institution or school possesses a certain response of motivation and it can be developed by teacher to accomplish learning productivity and encourage learner to be able to highly motivated and discipline in learning.

According to the observation conducted by the researchers, students in Daisoli Aileu District, Timor Leste come from diverse socio-economic condition backgrounds, such as different education degree, family's income, wealth and property owned, and the residential of family. At this point, the researchers are interested in scrutinizing whether the materials owned by the family of learners influences the learning outcomes. In addition, in fact, most students come to school by taking a walk and owned no amount of money to buy their needs in the school. Therefore, students, in fact, feel less motivated and discouraged which subsequently it dominantly influence the participation during teaching learning process and at the end of the day, such students achive less or have low learning outcomes.

\section{Research Purpose}

This present research is conducted to discover and examine the signficant influence between socioeconomic condition of family on learning motivation of students in Daisoli, Aileu District, Timor Leste.

\section{Research Hypothesis}

Pursuant to the background of the study above and purpose of this study, thus this research hypothesis deals with is there a significant influence between socio-economic condition of family on students' learning motivation in Daisoli, Aileu Disctrict, Timor Leste.

\section{LITERATURE REVIEW}

In general, economic condition is positively influenced on learning motivation of students in school. By owning a sufficient or great amount of capital, students are able to fulfill the needs of learning such as books, stationary, and any other needs. In addition, such a number of capital makes students could afford an additional benefit such as private learning or registering for a learning course outside the school. The more complete and better the learning facilities accessed by students the higher learning outcomes of students achieved. Individual possessing motivation or desire within him or herself will inevitably accomplish particular objective or goal compare to individual who requires a motivation outside the individual. This condition happens since the 
individual with initiative and willingness as well as motivation to accomplish expected objective by such individual occur. Commonly, such individual possesses an active characteristic. It is different from passive individual who requires an encouragement and motivation from other individual to accomplish certain objectives. Thus, the process of passive individual to achieve the goal is considered slower. Other perspective argues that motivation is defined as a changing process within the individual and it is indicated by the feeling and reaction of desire to accomplish the objective (Hamalik, 2002).

According to Soerjono Soekanto (2001), socioeconomic condition is an individual position within society in relation to other people in terms of social circumstance, achievement, and the rights and obligations which is related to the human resource. Socio-economic condition of each individual is different, in terms of capacity and degree - commonly classified as individual who has high, average, and low socio-economic degree.

According to Hamalik (2002), good socioeconomic condition could both encourage and hamper the process of students' learning. In addition, the capital owned by the individual takes a role as power resources. Thus, if the individual owns limited resource of financial, it hamper the learning. In fact, family's income serves as one contributing factor to children educational degree. Since undeniably, all facilities and necessities of children in school require an amount of money from the parents.

According to Soekanto (2001), there are several factors contributing to the degree of socio-economic condition of parents, which include: educational degree, occupation of parents, parents' income, residential condition of parents, property owned by parents, and parents' participation within community. Motivation is an intentional attempt to activate, direct, and keep individual's attitude in order to be encouraged in performing maximal effort in achieving particular goal and objective.

According to Hasibuan, motivation is defined as a set of forcé in directing a school and students in order to perform a achieved teaching and learning process (DeJesus, 2013). Therefore, in other words, motivation is the individual's tendency (a characteristic as a primary contradiction) which encourages the entire action and attitude. Motivation includes a biological and emotional needs which are observable from human being's attitude perspective.

\section{METHODS}

This research was conducted in Ensino Disoli Aileu District, Timor Leste. It was conducted for 14 days started from $2^{\text {nd }}$ of April until $15^{\text {th }}$ of April 2017. The research timeline is provided in the appendices. The population is a neither object nor subject located in particular area and meet a certain criteria which is related to the issues examined. This research took the entire students in Daisoli Alleu Districts, Rimor Leste amounted to 30 students. The data collection technique of this research was using observation, questionnaire, and documentation.

\section{RESULT}

According to the findings of the research, the researchers will initially discuss an issues regarding the teaching staffs in Ensino Daisoli Aileu District, Timor Leste. For the detailed information is presented in the following explanation.

\section{Gender}

From the entire number of teaching staffs in Ensino Daisoli Aileu District, Timor Leste, the description of the gender is illustrated in the following Table 1.

Table 1

Teaching Staffs' Gender Classification

\begin{tabular}{|c|c|c|c|}
\hline No & Gender & Total & Percentage \\
\hline 1 & Male & 13 & $92.86 \%$ \\
\hline 2 & Female & 1 & $7.14 \%$ \\
\hline & Total & 14 & $100 \%$ \\
\hline
\end{tabular}

According to the data above, the number of teaching staffs in Ensino Daisoli Aileu District, Timor Leste who are classified as male is amounted to 13 teaching staffs or $92.86 \%$ from the total teaching staffs is male. While the female teaching staff is only one person or $7.14 \%$.

\section{Educational Degree}

From the data of teaching staffs in Ensino Daisoli Aileu District, Timor Leste, the educational degree possessed is presented in the Table 2.

Table 2

Teachinh Staffs' Educational Degree

\begin{tabular}{clcc}
\multicolumn{4}{c}{ 'eachinh Staffs' Educational Degree } \\
\hline No & Educational Degree & Total & Percentage \\
\hline 1 & Bachelor's Degree & 1 & $7.14 \%$ \\
2 & Diploma 3 & 8 & $57.14 \%$ \\
3 & Diploma 2 & - & $0 \%$ \\
4 & Finalist & 2 & $14.29 \%$ \\
5 & High School & 3 & $21.43 \%$ \\
\hline \multicolumn{2}{r}{ Total } & $\mathbf{1 4}$ & $\mathbf{1 0 0 \%}$ \\
\hline
\end{tabular}

According to the data presented in Table 2, the teaching staff in Ensino Daisoli Aileu District, Timor Leste possessed a bachelor's degree is one person or equal to $7.14 \%$, the teaching staffs possessing Diploma 3 certificate are 8 persons or $57.14 \%$, the no teaching staff possessing Diploma 2 certificate, the teaching staffs possessing Finalist certificate are two persons or $14.29 \%$, while teaching staffs possessing High School certificate are three persons or $21.43 \%$.

\section{Validity Testing}

Within this research, it consists of two variables-independent and dependent variable. To ensure an uncomplicated calculation regarding validity testing, then SPSS program version 21.0 was employed in this research. If the result of $r$ is positive, $r_{\text {count }}>r_{\text {table, }}$ then the variable tested in this research is valid or the significance level $<0.05$. The following is the validity testing results for each variable: 
Variable $X$ Validity Testing

Table 3

The Results of Variable X Validity Testing

\begin{tabular}{ccccc}
\hline Item & $\mathbf{r}_{\text {count }}$ & $\mathbf{r}_{\text {table }}$ & $\begin{array}{c}\text { Significant } \\
\text { Level }\end{array}$ & Conclusion \\
\hline $\mathrm{X} 1$ & 0.573 & 0.361 & 0.000 & Valid \\
$\mathrm{X} 2$ & 0.526 & 0.361 & 0.001 & Valid \\
$\mathrm{X} 3$ & 0.515 & 0.361 & 0.002 & Valid \\
$\mathrm{X} 4$ & 0.684 & 0.361 & 0.000 & Valid \\
$\mathrm{X} 5$ & 0.608 & 0.361 & 0.000 & Valid \\
$\mathrm{X} 6$ & 0.508 & 0.361 & 0.002 & Valid \\
$\mathrm{X} 7$ & 0.494 & 0.361 & 0.003 & Valid \\
\hline
\end{tabular}

According to the validity testing, it shows that from seven items of variable $\mathrm{x}$, the entire items are valid which is greater than 0.361 with the significance level of $<0.05$.

\section{Variabel Y Validity Testing}

Table 4

The Results of Variable X Validity Testing

\begin{tabular}{ccccc}
\multicolumn{5}{c}{ The Results of Variable X Validity Testing } \\
\hline Item & $\mathbf{r}_{\text {count }}$ & $\mathbf{r}_{\text {table }}$ & $\begin{array}{c}\text { Significant } \\
\text { Level }\end{array}$ & Conclusion \\
\hline Y1 & 0.539 & 0.361 & 0.001 & Valid \\
Y2 & 0.542 & 0.361 & 0.001 & Valid \\
Y3 & 0.466 & 0.361 & 0.005 & Valid \\
Y4 & 0.611 & 0.361 & 0.000 & Valid \\
Y5 & 0.533 & 0.361 & 0.001 & Valid \\
Y6 & 0.725 & 0.361 & 0.000 & Valid \\
Y7 & 0.481 & 0.361 & 0.004 & Valid \\
\hline
\end{tabular}

According to the validity testing, it shows that from seven items of variable $\mathrm{Y}$, the entire items are valid which is greater than 0.361 with the significance level of $<0.05$. therefore, the instrument for both variable $\mathrm{X}$ (socio-economic condition of family) and $\mathrm{Y}$ (learning motivation) above is feasible for further analysis.

\section{Reliability Testing}

Reliability is an index indicating how far particular instrument is reliable or trustworthy to be implemented. The reliability testing of both variable $x$ and $y$ detailed with the calculation is presented in the following Table 5.

According to the validity testing above, it is known that the entire items of both variable $\mathrm{X}$ (socioeconomic condition of family) and variable Y (learning motivation) are considered reliable since the Crinbach's Alpha Value is greater than 0.6.

\section{Data Normality Testing}

Normality testing is employed to test whether within certain regression model, dependent variable, independent variable or both variable has a normal distribution. A good regression model is a data with a normal distribution or close to normal. The results of normality testing is presented in the following figure.

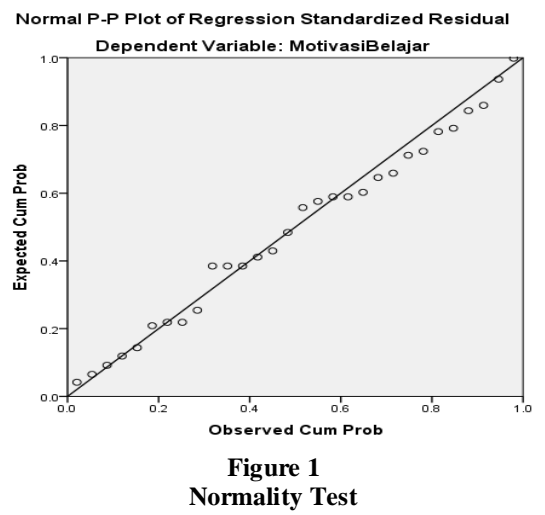

As presented in the figure 1 above, it illutrates a normal scatterplot graph. It is shown that the points are spread around diagonal line, and the spreading follows the diagonal line direction (generating a straight line). Thus, it can be said that the data are normally distributed and the regression model is feasible to be used to predict the learning achievement of the students in regard with the independent variable.

\section{Hypothesis Testing (t test)}

To discover the significant influence from independent variable, socio-economic condition of family, on the dependent variable, learning motivation in Ensino Daisoli Aileu District, Timor Leste the t test is performed. $\mathrm{T}$ test is performed by comparing the probability of $t_{\text {count }}$ with level of significance $(0.05)$. The detailed of $\mathrm{t}$ test is presented in the following Table 6.

Table 5

Variable Reliability Testing Results

\begin{tabular}{cccc}
\hline Variable & $\mathbf{r}_{\text {alfa }}$ & $\mathbf{r}_{\text {table }}$ & Conclusion \\
\hline $\mathrm{X}$ & 0.725 & 0.60 & Reliable \\
$\mathrm{Y}$ & 0.727 & 0.60 & Reliable \\
\hline
\end{tabular}

\begin{tabular}{|c|c|c|c|c|c|c|}
\hline \multicolumn{7}{|c|}{$T$ test } \\
\hline & \multirow[t]{2}{*}{ Model } & \multicolumn{2}{|c|}{ Unstandardized Coefficients } & $\begin{array}{c}\text { Standardized } \\
\text { Coefficients }\end{array}$ & \multirow[t]{2}{*}{$\mathrm{t}$} & \multirow[t]{2}{*}{ Sig. } \\
\hline & & $\mathrm{B}$ & Std. Error & Beta & & \\
\hline \multirow{2}{*}{1} & (Constant) & 11.384 & 2.021 & & 5.632 & .000 \\
\hline & Socio-economic condition & .645 & .091 & .801 & 7.091 & .000 \\
\hline
\end{tabular}

The regression analysis shows that in the independent degree of $\mathrm{df}=\mathrm{n}-\mathrm{k}-1=28$, on the confidence interval of $95 \%$ or error interval of 0.05 from the calculation obtain the probability value of $t_{\text {count }}$ amounted to 7.091 higher than $t_{\text {table }}$ of 1.701 on the error interval of 5\%. Therefore, Ho is rejected and 
$\mathrm{Ha}$ is accepted. If $\mathrm{Ha}$ is accepted, means that socioeconomic condition of family influences on learning motivation of students in Ensino Daisoli Alleu District, Timor Leste. Thus, it can be seen that the value for the socio-economic condition of family are 7,091 on $t_{\text {table }}$ with $28 \mathrm{db}$ and the significant level of 0.05 was obtained 1.701, since $t_{\text {count }}>t_{\text {table }}$ then Ho is rejected and $\mathrm{Ha}$ is accpeted. Based on the above analysis, for the simple linear regression equation on the Coefficients ttable, it can be said that:

$\mathrm{Y}=11.384+0.645 \mathrm{X}$

The interpretation of regression linear coefficient indicates that if the learning motivation is constant amounted to 11.384 . if the variable of socioeconomic condition of family increases one point, then the learning motivation variable will have positive influence amounted to 0.645 . The stages performed on partial hypothesis testing is explained as follows:

$\mathrm{H} 0: \mathrm{P}=0$, means, socio-economic condition variable $(\mathrm{X})$ has no influence on student motivation (Y).

$\mathrm{H} 1: \mathrm{P} \neq 0$, means, socio-economic condition variable $(\mathrm{X})$ has an influence effect on student motivation $(\mathrm{Y})$.

$$
\begin{aligned}
& \alpha=0.05 / 1 \text { with df }(\mathrm{n}-\mathrm{k}-1)=28 \\
& \mathrm{t}_{\text {table }} \quad=1,701 \\
& \mathrm{t}_{\text {tabel }} \quad=1.701
\end{aligned}
$$

Based on the calculation it obtained $t_{\text {count }}$ amounted to 7. $091>\mathrm{t}_{\text {table }}$ amounted to 1.701 then Ho is rejected at the $95 \%$ significance level, or the significant values of $t$ test of 0.000 which is smaller than $<5 \%$ so Ho rejected and $\mathrm{Hi}$ is accepted, so it can be concluded that the socio-economic condition variable has an influence on student learning motivation.

Meanwhile, the coefficient (R) is used to determine the relationship between the independent variable $(\mathrm{X})$ and dependent variable $(\mathrm{Y})$, if the correlation coefficient $(\mathrm{R})$ is close to 1 then the relationship is very strong and direct. If the correlation coefficient (R) closes to (-1) then the relationship strong and opposite directions, whereas if the value of the correlation coefficient $(\mathrm{R})$ is 0 then the relationship is weak.

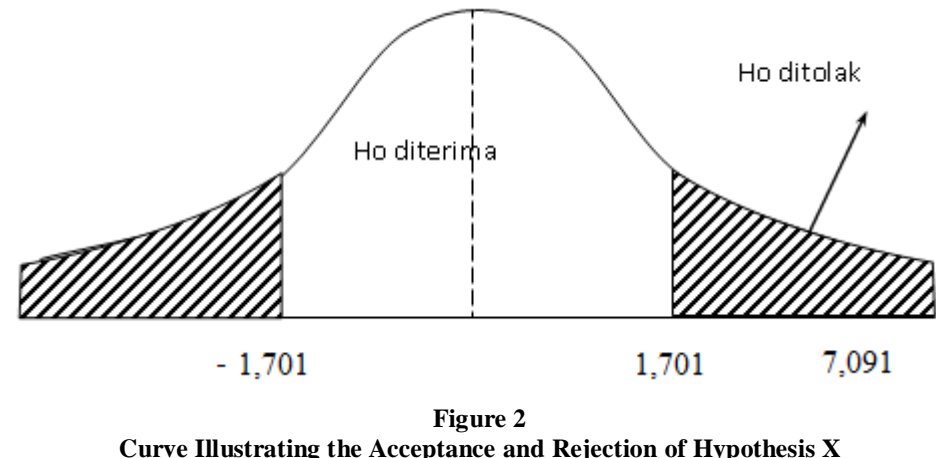

Curve Illustrating the Acceptance and Rejection of Hypothesis X

Table 7

Model Summary Model Summary ${ }^{\mathbf{b}}$

\begin{tabular}{l|r|r|r|r|r|}
\hline Model & $\mathrm{R}$ & R Square & $\begin{array}{c}\text { Adjusted R } \\
\text { Square }\end{array}$ & $\begin{array}{c}\text { Std. Error of the } \\
\text { Estimate }\end{array}$ & Durbin-Watson \\
\hline 1 & $.801^{\mathrm{a}}$ & .642 & .630 & 1.930 & 1.820 \\
\hline
\end{tabular}
a. Predictors: (Constant), Economic condition
b. Dependent Variable: learning motivation

From the analysis, the value of the correlation coefficient $(\mathrm{R})$ is 0.801 . These values indicate a positive influence and relationship is very strong and directional, meaning that if there is an increase in the independent variable, the socio-economic conditions of the family, it will be followed by an increase in the learning motivation of students and vice versa.

The determination coefficient $\mathrm{R}^{2}$ is amounted to 0,642 or $64,2 \%$. It means that $64.2 \%$ socio-economic condition of family determines the increasing and decreasing of students' learning motivation in Ensino Daisoli Alleu District, Timor Leste. Meanwhile, the rest of $35.8 \%$ are influenced by other factors which are not taken into account within this research.

\section{DISCUSSION}

Simple linear regression analysis result indicates that socio-economic condition of family has a significant influence on learning motivation of students in Ensino Daisoli Aileu District, Timor Leste amounted to $64.2 \%$. Meanwhile, the rest of $35.8 \%$ are influenced by other factors which are not taken into account within this research.

According to the research result in Ensino Daisoli Aileu District, Timor Leste by providing seven items of questionnaire regarding socio-economic condition of family and seven item regarding learning motivation on 30 respondents. The results of research and analysis from SPSS Program version 21.0, it indicates that the t-test demonstrates that the socioeconomic condition of family has a significant influence on learning motivation in Ensino Daisoli Aileu District, Timor Leste with $t_{\text {count }}$ amounted 7.091 is higher than $t_{\text {table }}$ amounted to 1.701 with the error interval of $5 \%$. Therefore, the hypothesis alternative $\left(\mathrm{H}_{\mathrm{a}}\right)$ is accepted and Ho is rejected. 
Thus, it can be explained that the motivation to learn is the attempt of the students to follow the teaching and learning activities in order to achieve the expected goals and it is indicated by test scores or the number of test or evaluation performed by families and teachers during students' education in Ensino Daisoli Aileu District - Timor Leste. In addition, motivation is a conscious effort to move, direct and maintain one's behavior in this case the student to feel compelled to act to do something to achieve a certain result or goal.

The results showed that in order to increase students 'motivation, it needs the support of the family in terms of socio-economic conditions to increase students' daily needs or other needs in the school, it will provide a contribution of 0.642 or $64.3 \%$.

\section{CONCLUSION}

According to the analysis of data obtained and the discussion of findings, therefore, the researchers could draw a conclusion which states that there is a significant influence of socio-economic condition of family on learning motivation in Ensino Daisoli Aileu District, Timor Leste. Where $t_{\text {count }}$ amounted 7.091 is higher than $t_{\text {table }}$ amounted to 1.701 with the error interval of $5 \%$. Therefore, the hypothesis alternative $\left(\mathrm{H}_{\mathrm{a}}\right)$ is accepted and Ho is rejected. As for the simple linear regression equation is $\mathrm{Y}=11,381+0.645 \mathrm{X}$. in addition, The determination coefficient $\mathrm{R}^{2}$ is amounted to 0,642 or $64,2 \%$. It means that $64.2 \%$ socio-economic condition of family determines students' learning motivation in Ensino Daisoli Alleu District, Timor Leste.

\section{REFERENCES}

[1] DeJesus, A. S. V. 2013. Pengaruh Lingkungan Sekolah terhadap Motivasi Belajar Siswa Kelas III di Ensino Basico Catolica ${ }^{0}$ Ciclo São João Brito Liquica. Thesis. Dili: Instituto Superior Cristaal, Balide Dili.

[2] Hamalik, O. 2002. Perencanaan Pengajaran Berdasarkan Pendekatan Sistem. Jakarta: Bumi Aksara.

[3] Hasan. 2002. Hubungan Tingkat Pendidikan dan Pendapatan dengan Partisipasi Orang Tua dalam Pengelolaan Pendidikan di Madrasah Tsanawiyah dengan Prestasi. Thesis. Makassar: State University of Makasar.

[4] Soekanto, S. 2001. Sosiologi Suatu Pengantar. Jakarta: Rajawali Press. 